Volume 10 Issue 3, July-September 2016: pp. 413-. Copyright (c) 2015-2016 FIAT JUSTISIA. Faculty of Law, Lampung University, Bandarlampung, Lampung, Indonesia. ISSN: 1978-5186 | e-ISSN: 2477-6238.

Open Access: http://jurnal.fh.unila.ac.id/index.php/fiat

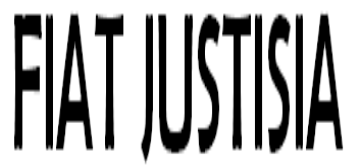

Fiat Justisia is licensed under a Creative Commons Attribution 4.0 International License, which permits unrestricted use, distribution, and reproduction in any medium, provided the original work is properly cited.

\title{
PENGUATAN KELEMBAGAAN PENGAWAS PEMILU DALAM PENYELENGGARAAN PEMILIHAN KEPALA DAERAH DAN WAKIL KEPALA DAERAH ${ }^{1}$
}

\section{Strengthening Institutions Supervision of Elections in the Implementation of the Election of Regional Head and Regional Deputy Head}

\author{
Erwin Prima Rinaldo \\ Badan Pengawas Pemilihan Umum Provinsi Lampung \\ email: ep.rinaldo@gmail.com
}

\begin{abstract}
Democracy substance is "raison de etre" on regulating direct election system and it's position about implementation principle of the state by law. Based on evaluating in 2005 until 2014, conducted alteration for implementation system, who reflected alteration policy purpose about election supervisor institute. An aim of this research is (a) to explain the direction of reinforcement supervisor election institute policies based on Law Number 1 of 2015 attached its alteration, and (b) the impact of reinforcement concerning institutional capacity. This research used juridical normativism method, through statue approach, conceptual and institutional in an integrative manner. Data resources used a secondary material with qualitative analysis technique.These research conclude the direction policies about reinforcement has been formed by enforcement duties, authority, obligation, character and function head for transformation as control institution. An impact about institution capacity is forming mechanism not including for enforcement capacity orientation, asymmetry on implementation administrative function, procedure, and finances ordering, rather regulation quality from Bawaslu with the result obstruction concerning the effectiveness of institutionally implementation function. Suggestion is (a) upgrading typology of Election Supervisor Board Province
\end{abstract}

1 Tinjauan Yuridis Normatif terhadap Kelembagaan Pengawas Pemilu dalam Penyelenggaraan Pemilihan Kepala Daerah dan Wakil Kepala Berdasarkan Undang-Undang Nomor 1 Tahun 2015 dan Peraturan Perundangan Perubahannya. 
and alteration characteristic Election Supervisor Kabupaten/Kota become permanent institution or increasing quality, quantity and qualification human resources, (b) correction regulating about procedure and duty on pieces as integrative, also (c) completing regulation about observatory implementation function based on norm and rule pursuant to election ordinance.

Keywords: Institusional Reinforcement, Election Supervisor and Local Election

\begin{abstract}
Abstrak
Substansi demokrasi merupakan raison de etre Pilkada secara langsung dan menegaskan kedudukannya atas implementasi prinsip negara hukum. Berdasarkan evaluasi tahun 2005 s.d 2014, dilakukan perubahan sistem penyelenggaraan yang merefleksikan perubahan arah kebijakan terhadap kelembagaan pengawas Pemilu. Tujuan penelitian ini (a) menjelaskan arah kebijakan penguatan kelembagaan pengawas Pemilu berdasarkan UndangUndang Nomor 1 Tahun 2015 beserta peraturan perundangan perubahannya, dan (b) dampak penguatan terhadap kapasitas lembaga. Penelitian ini menggunakan metode yuridis normatif, melalui pendekatan undang-undang, konseptual dan kelembagaan secara integratif, menggunakan sumber data sukunder dengan teknik analisis kualitatif. Disimpulkan penguatan kelembagaan diwujudkan melalui penguatan tugas, kewenangan, kewajiban, peran dan fungsi kelembagaan yang mengarah transformasi fungsi sebagai institusi kontrol. Dampak terhadap kapasitas lembaga diantaranya mekanisme pembentukan belum berorientasi penguatan kapasitas, kesenjangan penatalaksanaan fungsi administrasi, tata kerja dan penatausahaan keuangan, serta lemahnya kualitas Peraturan-Peraturan Bawaslu yang menghambat efektifitas fungsi kelembagaan. Disampaikan saran (a) peningkatan tipelogi Bawaslu Provinsi dan perubahan kelembagaan ditingkat Kabupaten/Kota menjadi bersifat tetap dan/atau peningkatan kualitas, kuantitas dan kualifikasi SDM (b) pembenahan regulasi tata kerja dan uraian tugas secara integratif, serta (c) penyempurnaan regulasi pengawasan Pemilu berdasarkan norma dan kaidah peraturan perundangundangan.
\end{abstract}

Kata Kunci: Penguatan Kelembagaan, Pengawas Pemilu dan Pilkada

\title{
A. Pendahuluan
}

Substansi demokrasi dalam pembentukan penyelenggara pemerintahan daerah pasca perubahan kedua Undang-Undang Dasar (UUD Negara Republik Indonesia Tahun 1945 sebagaimana amanat Pasal 18 ayat 
(4) yang diwujudkan mlalui pembentukan peraturan perundangan yang mengatur pelaksanaan pemilihan kepala daerah dan wakil kepala daerah (Pilkada) secara langsung, merupakan raison de etre yang menjadi esensi dasar demokratisasi penyelenggaraan pemerintahan daerah. Evaluasi terhadap perkembangan penyelenggaraan Pilkada secara langsung tahun 2005 s.d 2014, melahirkan pandangan bahwa penyelenggaraan pemilihan gubernur, bupati, dan walikota secara langsung selama ini, diliputi oleh maraknya berbagai permasalahan yang tidak berkesesuaian dengan prinsipprinsip demokrasi.

Hal tersebut menjadi dasar pijak dilakukannya perubahan terhadap Undang-Undang Nomor 32 Tahun 2004 a quo, dengan kerangka dasar yaitu pemisahan peraturan perundangan mengenai pemerintahan daerah terhadap peraturan perundangan mengenai penyelenggaraan Pilkada, dengan sasaran yaitu mewujudkan penyelenggaraan Pilkada secara demokratis berdasarkan asas-asas Pemilu, yaitu langsung, umum, bebas, rahasia, jujur dan adil, yang dalam pelaksanaannya membutuhkan kemandirian dan kredibilitas penyelenggara Pemilu untuk mewujudkan integritas proses dan hasil Pilkada.

Penyempurnaan sistem perundang-undangan kepemiluan untuk mewujudkan kelembagaan penyelenggara Pemilu yang mandiri, kredibel dan berintegritas, bersifat penting terhadap tegaknya asas-asas Pemilu serta terwujudnya integritas Pilkada sebagaimana di atas, sebagai bagian dari upaya perkuatan pranata demokrasi dan pembangunan tata hukum. Hal tersebut utamanya penanganan berbagai permasalahan kepemiluan, baik pada lingkup norma-norma maupun implementasi dari norma pada tata aturan, diantaranya yaitu manipulasi persyaratan pencalonan, in-validitas data pemilih, politik uang dalam kampanye, penyalahgunaan kewenangan dan intervensi struktur kekuasaan, serta penggelembungan hasil perolehan suara sebagai fenomena umum pada hampir setiap pelaksanaan kepemiluan, yang melibatkan penyelenggara Pemilu, peserta Pemilu dan/atau masyarakat sebagai pemilih.

Upaya mengatasi permasalahan di atas menjadi landas pijak penguatan kedudukan kewenangan kelembagaan pengawas Pemilu yang bersifat nasional, tetap dan mandiri sebagaimana amanat Pasal 22E ayat (5) UUD Tahun 1945. Keberadaan pengawas Pemilu dalam tinjauan politik dan hukum administrasi, bersifat penting untuk menghindari delegitimasi proses dan hasil Pemilu, serta antisipasi perkembangan berbagai tindak pelanggaran berdasarkan tata hukum secara, guna perkuatan kepercayaan masyarakat atas berbagai permasalahan sistem kepemiluan ${ }^{2}$. Keberadaan pengawas Pemilu

\footnotetext{
${ }^{2}$ Sardini, Nurhidayat. (2009). Pedoman Pengawasan Pemilu. Jakarta: Election-MDP, p. 3.
} 
yang kuat tidak terlepas dari pentingnya mekanisme pengawasan demi terwujudnya Pemilu yang berkualitas ${ }^{3}$.

Kerangka pemikiran di atas merupakan dasar pijak upaya pembenahan secara mendasar aspek-aspek tata laksana, hubungan kewenangan antar penyelenggara Pemilu dan penguatan kedudukan kewenangan kelembagaan pengawas Pemilu berdasarkan Undang-Undang Nomor 1 Tahun 2015 beserta peraturan perundangan perubahannya, sehingga menghadirkan berbagai ketentuan baru yang belum pernah terdapat pada sistem perundangundangan sebelumnya yang mengatur tentang sistem penyelenggaraan Pilkada.

Upaya pembenahan sebagaimana di atas di wujudkan melalui pengembangan susunan organisasi dan struktur kewenangan kelembagaan pengawas Pemilu, serta perubahan tata laksana dan hubungan kewenangan antar penyelenggara Pemilu, yang merefleksikan perubahan politik hukum terhadap kelembagaan pengawas Pemilu. Untuk itu, perlu dilakukan tinjauan mengenai arah kebijakan penguatan kelembagaan Pengawas Pemilu dalam penyelenggaraan Pilkada, serta dampak penguatan kelembagaan pengawas Pemilu terhadap kapasitas lembaga dalam mewujudkan tujuan penguatan sistem pengawasan Pilkada.

Penelitian ini mengkaji norma dan kaidah-kaidah penyelenggaraan pengawasan Pemilu khususnya yang berkaitan dengan kelembagaan pengawas Pemilu dan penyelenggaraan Pilkada, sehingga penelitian ini mengggunakan metode yuridis normatif dan bersifat dekriptif analitis, untuk meneliti arah penguatan kelembagaan serta dampaknya terhadap kapasitas kelembagaan dalam implementasi tugas, kewenangan dan kewajiban ${ }^{4}$.

\section{B. Pembahasan}

\section{Arah Kebijakan Terhadap Kelembagaan Pengawas Pemilu}

Evaluasi terhadap perkembangan penyelenggaraan Pilkada tahun 2005 s.d 2014, melahirkan pandangan bahwa penyelenggaraan pemilihan gubernur, bupati, dan walikota secara langsung diliputi maraknya berbagai permasalahan yang tidak berkesesuaian dengan prinsip-prinsip demokrasi ${ }^{5}$. Untuk itu diperlukan kerangka upaya untuk mewujudkan integritas proses dan hasil penyelenggaraan Pilkada secara langsung, melalui perkuatan pranata demokrasi berdasarkan tata hukum pada lingkup norma maupun

3. Satriawan, Iwan. (2016). "Pengawasan Pemilukada oleh Rakyat", Jurnal Bawaslu, 2(1): 115.

4. Muyassarotussolichah. "Melacak Akar, Cabang dan Ranting Politik Hukum UUD 1945 Hasil Amandemen", http://ern.pendis.kemenag.go.id, (dikutip tanggal 29 Juli 2016).

5 . Lihat bagian menimbang pada uraian huruf $b$ dan huruf c pada Undang-Undang Nomor 22 Tahun 2014 tentang Pemilihan Gubernur, Bupati dan Walikota. 
kaidah-kaidah dalam implementasi tata aturan sistem penyelenggaraan Pilkada.

Upaya pembenahan secara mendasar aspek-aspek tata laksana, hubungan kewenangan antar penyelenggara Pemilu dan penguatan kedudukan kewenangan kelembagaan pengawas Pemilu melalui pembentukan Undang-Undang Nomor 1 Tahun 2015 a quo beserta peraturan perundangn perubahannya, menghadirkan berbagai ketentuan baru yang belum pernah terdapat pada sistem perundang-undangan sebelumnya, terutama yang berkaitan dengan implementasi tugas, wewenang dan kewajiban dalam penyelenggaraan Pilkada.

Pada aspek kelembagaan, perubahan tersebut diwujudkan melalui (a) pembentukan ketentuan bahwa pengawasan penyelenggaraan Pemilihan menjadi tanggung jawab bersama Bawaslu, Bawaslu Provinsi dan Panwas Kabupaten/Kota, (b) pembentukan ketentuan mengenai uraian tugas, wewenang dan kewajiban masing-masing kelembagaan pengawas Pemilu dalam implementasi fungsi pengawasan Pilkada, (c) pembentukan ketentuan mengenai uraian kewenangan serta mekanisme dalam penanganan pelanggaran dan penyelesaian sengketa, (d) perluasan wilayah tugas melalui penguatan peran dan fungsi dalam implementasi pengawasan Pilkada, serta (e) pembentukan ketentuan-ketentuan mengenai tugas dan kewajiban KPU beserta jajarannya atas tindaklanjut implementasi tugas dan kewenangan Bawaslu beserta jajarannya.

Pengawasan terhadap implementasi asas-asas Pemilu bersifat objektif yang berlaku dalam proses atau berkenaan dengan mekanisme Pemilu, merupakan implementasi fungsi pengawasan kepemiluan yang diwujudkan melalui pembentukan ketentuan mengenai kewenangan kelembagaan pengawas Pemilu di semua tingkatan untuk :

a. mengawasi pelaksanaan seluruh tahapan-tahapan Pilkada, mulai dari pemutakhiran data dan penetapan daftar pemilih tetap sampai dengan proses penetapan hasil Pilkada, sebagaimana ketentuan Pasal 28 ayat (1) huruf a vide Pasal 30 (1) huruf a Undang-Undang Nomor 8 Tahun 2015 a quo;

b. menerima laporan dugaan pelanggaran serta memberikan rekomendasi kepada instansi yang berwenang di tingkatan masing-masing atas temuan dan/atau laporan dugaan pelanggaran dalam pelaksanaan peraturan perundang-undangan mengenai Pilkada, sebagaimana ketentuan Pasal 28 ayat (1) huruf $\mathrm{c}$ s.d huruf $\mathrm{f}$ vide Pasal 30 huruf $\mathrm{b}$ s.d huruf f UndangUndang Nomor 8 Tahun 2015 a quo; dan

c. melaksanakan kewenangan penyelesaian sengketa antar-peserta Pilkada berdasarkan ketentuan Pasal 142 s.d Pasal 144 Undang-Undang Nomor 8 Tahun 2015 a quo. 
Pengawasan terhadap implementasi asas-asas Pemilu yang terkait dengan sifat-sifat subjektif penyelenggara Pemilu, diwujudkan melalui pembentukan ketentuan mengenai kewenangan kelembagaan pengawas Pemilu untuk :

a. menyampaikan laporan kepada Bawaslu sebagai dasar mengeluarkan rekomendasi yang berkaitan dengan adanya dugaan tindakan yang mengakibatkan terganggunya tahapan penyelenggaraan Pemilihan oleh jajaran pelaksana Pemilihan,

b. memberikan rekomendasi kepada KPU dan/atau KPU Provinsi untuk menonaktifkan sementara dan/atau mengenakan sanksi administratif atas pelanggaran peraturan perundangan-undangan oleh jajaran pelaksana, mulai dari tingkat KPU sampai dengan KPPS yang mengakibatkan terganggunya tahapan penyelenggaraan Pemilihan,

c. mengawasi pelaksanaan sosialisasi penyelenggaraan Pilkada oleh KPU Provinsi dan Kabupaten/Kota, serta PPK, PPS dan KPPS, (d) melaksanakan kewenangan penyelesaian sengketa antara peserta dengan penyelengggara sebagai akibat dikeluarkannya Keputusan KPU Provinsi dan KPU Kabupaten/Kota, dan

d. Panwas Kabupaten/Kota mengawasi pelaksanaan rekrutmen PPK, PPS dan KPPS, serta mengawasi proses rekapitulasi suara yang dilakukan oleh KPU Provinsi dan KPU Kabupaten/Kota dari seluruh Kecamatan berdasarkan ketentuan Pasal 30 huruf a angka 1 dan angka 11 UndangUndang Nomor 10 Tahun 2016 a quo.

Pengaturan lebih lanjut mengenai pengawasan terhadap implementasi asas Pemilu yang terkait dengan sifat subjektif penyelenggara Pemilu, pada aspek hubungan kewenangan antar penyelenggara Pemilu diwujudkan melalui pembentukan ketentuan sebagai berikut :

a. Pengaturan mengenai tugas serta kewajiban KPU Provinsi dan KPU Kabupaten/Kota berdasarkan ketentuan Pasal 11 huruf $\mathrm{n}$ dan o vide Pasal 13 huruf $\mathrm{n}$ dan huruf o vide Pasal 193 ayat (2) Undang-Undang Nomor 8 Tahun 2015 a quo, untuk menindaklanjuti dengan segera rekomendasi Bawaslu Provinsi dan/atau Panwas Kabupaten/Kota atas temuan dan laporan pelanggaran, serta menindaklanjuti rekomendasi mengenakan sanksi administratif dan/atau menonaktifkan sementara anggota KPU Kabupaten/Kota dan/atau kecamatan, Sekretaris dan pegawai Sekretariat yang terbukti melakukan tindakan mengakibatkan terganggunya tahapan penyelenggaraan Pemilihan, yang disertai sanksi peringatan lisan atau peringatan tertulis berdasarkan ketentuan Pasal 141 Undang-Undang Nomor 8 Tahun 2015 a quo terhadap KPU Provinsi, KPU Kabupaten/Kota, PPK dan PPS atau peserta Pemilihan yang tidak menindaklanjuti rekomendasi tersebut sebagai dengan peraturan perundang-undangan. 
b. Pembentukan ketentuan mengenai tugas serta kewajiban PPK dan PPS berdasarkan ketentuan Pasal 18 huruf k vide Pasal 21 huruf s UndangUndang Nomor 8 Tahun 2015 a quo, untuk menindaklanjuti dengan segera rekomendasi Panwas Kecamatan dan PPL atas temuan dan laporan pelanggaran Pemilihan; dan

c. Pembentukan ketentuan mengenai kewajiban KPU Provinsi dan KPU Kabupaten/Kota berdasarkan ketentuan Pasal 12 huruf g vide Pasal 14 huruf $\mathrm{h}$ Undang-Undang Nomor 8 Tahun 2015 a quo, untuk menyampaikan laporan periodik mengenai tahapan penyelenggaraan Pemilihan serta menyampaikan tembusannya kepada Bawaslu dan/atau Bawaslu Provinsi, yang disertai ketentuan sanksi pidana terhadap KPU Provinsi dan KPU Kabupaten/Kota apabila tidak memenuhi ketentuan mengenai kewajiban tersebut berdasarkan ketentuan Pasal 193A ayat (1) dan ayat (2) Undang-Undang Nomor 10 Tahun 2015 a quo.

Mengacu konstruksi pemikiran mengenai penguatan kedudukan kewenangan kelembagaan pengawas Pemilu sebagaimana di atas, maka normatif arah kebijakan penguatan kelembagaan selanjutnya mengemuka dalam peran mewujudkan penyelenggaraan Pilkada secara demokratis berdasarkan asas - asas kepemiluan, serta terjaganya integritas proses dan hasil penyelenggaraan Pilkada. Peran pada bagian ini adalah amanat peraturan perundangan kepada kelembagaan pengawas Pemilu, untuk mengawasi pelaksanaan ketentuan-ketentuan yang berkaitan dengan tata laksana sistem penyelenggaraan di luar ketentuan mengenai uraian tugas, kewenangan dan kewajiban.

Tinjauan peran berdasarkan konsepsi di atas, terefleksi pada kondisi yang diharapkan dalam implementasi tugas dan kewenangan kelembagaan untuk menerima, menangani dan meneruskan dugaan pelanggaran, serta implementasi fungsi mencegah dan memastikan bahwa penyelenggaraan tahapan-tahapan Pilkada mematuhi norma-norma dan kaidah berdasarkan peraturan perundangan. Berdasarkan uraian tersebut, terlihat transformasi implementasi fungsi pengawasan kepemiluan sebagai institusi kontrol terhadap sistem penyelenggaraan Pilkada, yang tercermin pada :

a. proses rekrutmen kelembagaan pengawas Pemilu oleh masing-masing lembaga pengawas Pemilu pada 1 (satu) tingkatan di atasnya;

b. pelaksanaan tugas dan kewajiban, kelembagaan pengawas Pemilu telah memiliki kewenangan pengawasan terhadap pelaksanaan tahapan-tahapan kepemiluan, penanganan laporan/temuan pelanggaran dan penerusan laporan pelanggaran kepada institusi yang berwenang;

c. implementasi fungsi pengawasan oleh kelembagaan telah menekankan kepada aspek pencegahan pelanggaran secara terstruktur;

d. kelembagaan pengawas Pemilu telah memiliki kewenangan melakukan law enforcement, yaitu penetapan sanksi (punishment) pembatalan calon 
yang terbukti melakukan pelanggaran menjanjikan/memberikan uang atau lainnya secara terstruktur, sistematis dan massif untuk mempengaruhi penyelenggara/pemilih, dimana pembentukan Sentra Gakkumdu sebagai lembaga yang bersifat melekat pada Bawaslu Provinsi dan/atau Panwas Kabupaten/Kota dengan kewenangan melakukan penyelidikan melalui tindakan penggeledahan, penyitaan dan pengumpulan alat bukti untuk kepentingan penyidikan tanpa surat izin Ketua Pengadilan Negeri setempat merupakan manivestasi dari penguatan kelembagaan pengawas Pemilu dalam melakukan law enforcement terhadap penyelenggaraan Pilkada;

e. implementasi tugas, kewenangan dan fungsi kelembagaan pengawas Pemilu telah dapat menjangkau lembaga pelaksana Pemilu, sebagaimana tercermin dalam pembentukan ketentuan mengenai pengawasan secara langsung kegiatan pelaksana Pemilu, kewenangan memberikan peringatan dan sanksi kepada pelaksana Pemilu, serta kewajiban pelaksana Pemilu untuk segera menindaklanjuti putusan/rekomendasi oleh pengawas Pemilu;

f. kewenangan memutus sengketa antar-peserta dan peserta dengan penyelenggara dengan Putusan yang bersifat mengikat dan wajib ditindaklanjuti oleh KPU Provinsi dan KPU Kabupaten/Kota, sebagai manivestasi penguatan kelembagaan pengawas Pemilu untuk melakukan judgement terhadap penyelenggaraan Pilkada; dan

g. kelembagaan pelaksana Pemilu diwajibkan untuk menyampaikan laporan dan menembuskannya kepada kelembagaan pengawas Pemilu.

\section{Dampak Penguatan Kelembagaan Pengawas Pemilu Terhadap Kapasitas Lembaga Dalam Penyelenggaraan Pilkada}

Penguatan tugas, kewenangan dan kewajiban kelembagaan pengawas Pemilu dalam mencegah tindak pelanggaran, penanganan pelanggaran dan penyelesaian sengketa, serta peran memastikan bahwa penyelenggaraan tahapan-tahapan Pilkada mematuhi norma-norma dan kaidah peraturan perundangan, merefleksikan perluasan wilayah tugas kelembagaan pengawas Pemilu dalam mewujudkan Pilkada secara LUBER dan Jurdil. Sehubungan dengan hal tersebut, perlu dilakukan tinjauan mengenai dampak penguatan kelembagaan terhadap kapasitas lembaga untuk mengurai efektifitas pencapaian tujuan pengawasan Pilkada oleh kelembagaan pengawas Pemilu berdasarkan normatifisme Undang-Undang Nomor 1 Tahun 2015 a quo beserta peraturan perundangan perubahannya. 


\section{a. Tinjauan Pembentukan Pengawas Pemilu}

Merujuk normatif pembentukan kelembagaan pengawas Pemilu berdasarkan ketentuan Pasal 12 vide Pasal 86 s.d Pasal 89 Undang-Undang Nomor 15 Tahun 2011 a quo, tidak dapat dinafikan perkembangan dan konstatasi politik dalam pembentukan Bawaslu sebagai hulu pembentukan kelembagaan pengawas Pemilu, terhadap proses pembentukan kelembagaan pengawas Pemilu sampai ke tingkatan yang paling rendah.

Mekanisme pembentukan Bawaslu Provinsi dan Panwaslu Kabupaten/Kota serta ketentuan mengenai persyaratan calon Anggota pengawas Pemilu di semua tingkatan, secara umum belum berorientasi kepada penguatan kelembagaan, serta konstatasi politis pembentukan kelembagaan pengawas Pemilu dimasing-masing tingkatan. Hal tersebut terkait permasalahan relatif besarnya bobot subjektifitas di dalam penilaian kapasitas calon anggota pasca pelaksanaan tes tertulis oleh Tim Seleksi dan/atau rapat pleno penetapan calon terpilih, serta tes tertulis secara manual yang membuka peluang manipulasi hasil penilaian objektif mengenai kemampuan dan wawasan kepemiluan.

Mengenai waktu pembentukan Panwas Kabupaten/Kota, Panwas Kecamatan dan PPL yang dilaksanakan paling lambat 1 (satu) bulan sebelum Tahapan Persiapan dimulai serta dibubarkan paling lambat 2 (dua) bulan setelah seluruh Tahapan Penyelenggaran selesai, dimana pengaturan mengenai rincian Tahapan Persiapan dan Tahapan Penyelenggaraan dilaksanakan berdasarkan Peraturan KPU tentang Tahapan, Program dan Jadwal, merupakan permasalahan yang perlu menjadi perhatian karena menyebabkan ketidakpastian hukum atas waktu pembentukan kelembagaan pengawas Pemilu di tingkat Kabupaten/Kota sampai dengan PPL.

Pada bagian berikutnya, permasalahan mengenai waktu di atas berkelindan terhadap ketentuan berdasarkan Peraturan Menteri Dalam Negeri Republik Indonesia Nomor 44 Tahun 2015 a quo, yang menetapkan masa tugas Panwas Kabupaten/Kota 12 (dua belas) bulan, Panwas Kecamatan 9 (sembilan) bulan, dan PPL selama 6 (enam) bulan. Permasalahan atas implementasi ketentuan tersebut bersifat krusial karena berimplikasi kepada:

1) penetapan waktu pelaksanaan pembentukan Panwas Kabupaten s.d PPL setelah terbitnya Peraturan KPU tentang Tahapan, Program dan Jadwal Pilkada;

2) Panwas Kabupaten tidak dapat melakukan pengawasan terhadap Tahapan Persiapan yang bersifat strategis, diantaranya yaitu pembentukan perangkat pelaksana ad hoc, pendaftaran pemantau Pilkada, penyerahan daftar penduduk potensial Pemilih, dan terutama pembahasan rencana anggaran pengawasan Pilkada; dan 
3) kebergantungan kinerja kelembagaan pengawas Pemilu dalam pembentukan perangkat pengawasan Pilkada, yang berdampak kepada pelemahan kemandirian kelembagaan pengawas Pemilu.

Selanjutnya, pengaturan masa kerja berdasarkan Permendagri di atas berimplikasi kepada in-efektifitas implementasi pengawasan tahapantahapan Pilkada, mengingat berdasarkan telaah terhadap Peraturan KPU Nomor 2 Tahun 2015 Jo. Peraturan KPU Nomor 3 Tahun 2016, bahwa waktu pelaksanaan Pilkada secara keseluruhan dilaksanakan selama 13 (tiga belas) bulan. Pada bagian berikutnya, tinjauan terhadap perangkat regulasi tersebut bersifat krusial terhadap kesamaan persepsi dengan TAPD dalam pembahasan RKA Pengawasan Pilkada, dan terutama antisipasi permasalahan hukum atas penatalaksanaan anggaran dalam pelaksanaan pertanggungjawaban keuangan.

\section{b. Tata Kerja Kelembagaan, Susunan Organisasi Sekretariat dan Dukungan Anggaran}

Pelaksanaan pembinaan dan pengawasan terhadap kinerja kelembagaan pengawas Pemilu tingkatan di bawahnya merupakan upaya antisipasi terhadap kecenderungan lemahnya kapasitas kelembagaan Panwas Kabupaten/Kota dalam penatalaksanaan organisasi dan penatausahaan administrasi, sebagai implikasi dari permasalahan kedudukan kelembagaan Panwas Kabupaten/Kota yang bersifat ad hoc.

Optimalisasi penyelenggaraan tugas, kewenangan dan kewajiban menghadapi kendala terkait substansi Peraturan Bawaslu mengenai Tata Kerja dan Peraturan Bawaslu mengenai Pengawasan Tahapan-Tahapan Pilkada, yang belum menguraikan secara teknis mekanisme, ruang lingkup, hubungan fungsional antar kompartemen secara internal dan eksternal, serta capaian sasaran. Hal tersebut perlu menjadi perhatian, terkait peran penting Pokja dalam mengintegrasikan fungsi divisi-divisi dan uraian tugas masingmasing sub-bagian pada Sekretariat guna penguatan kapasitas kelembagaan serta akuntabilitas kinerja. Permasalahan selanjutnya mengemuka pada disparitas fungsi divisi-divisi terhadap uraian tugas sub-bagian pada Sekretariat Bawaslu Provinsi yang bersifat asimetris, serta inproporsionalitas beban tugas Subbagian Teknis Penyelenggaraan Pengawasan Pemilu dan Subbagian Administrasi pada Sekretariat Bawaslu Provinsi.

Pada bagian berikutnya, implementasi ketentuan bahwa penganggaran, pelaksanaan dan penatausahaan, serta pelaporan dan pertanggungjawaban dana hibah Pilkada berpedoman pada peraturan perundang-undangan yang mengatur pengelolaan APBN, pada tingkat Panwas Kabupaten/Kota menghadirkan kendala dalam penatalaksanaan anggaran lebih lanjut, sebagai implikasi kedudukan kelembagaan yang 
bersifat ad hoc. Kondisi tersebut mengemuka pada kapasitas sumberdaya manusia dalam implementasi anggaran berdasarkan mekanisme pengelolaan APBN, serta kesiapan dalam implementasi pengesahan dana hibah yang berimplikasi kepada terhambatnya kelancaran penatausahaan keuangan yang memberi dampak langsung terhadap kinerja jajaran Panitia Pengawas Pilkada.

\section{c. Penyelenggaraan Tugas, Kewenangan dan Kewajiban Dalam Pelaksanaan Pengawasan Tahapan-Tahapan Pilkada}

Secara normatif perlu dilakukan tinjauan terhadap arah, penatalaksanaan fungsi dan kepastian hukum dalam implementasi fungsi pengawasan terhadap pelaksanaan tahapan-tahapan Pilkada berdasarkan Peraturan-Peraturan Bawaslu. Hal tersebut bersifat krusial mengingat kedudukan Bawaslu sebagai lembaga negara yang melaksanakan atribusi kewenangan pembentukan peraturan perundang-undangan bidang pengawasan Pemilu (law-creating function). Dalam pendekatan capacity building, produk lembaga dan faktor manajemen yang membuat produk kelembagaan tersebut merupakan refleksi secara nyata kapasitas kelembagaan (institutional capacity).

Permasalahan pokok substansi Peraturan-Peraturan Bawaslu mengenai implementasi fungsi pengawasan tahapan-tahapan Pilkada, yaitu kecenderungan lemahnya korespondensi ketentuan-ketentuan dalam Peraturan-Peraturan Bawaslu terhadap norma primer dan norma-norma sekunder berdasarkan peraturan perundangan tentang Pilkada ${ }^{6}$, terutama yang berkaitan dengan implementasi ketentuan perintah kepada penyelenggara Pemilu, peserta Pilkada dan/atau masyarakat sebagai subjek hukum, serta penegakan ketentuan larangan sebagai core function fungsi kelembagaan dalam pencegahan dan penanganan pelanggaran.

Pada bagian berikutnya, terdapat permasalahan kesesuaian arah yang meliputi (a) perubahan hubungan kewenangan antar kelembagaan penyelenggara Pemilu dalam penyelenggaraan ketentuan mengenai tugas, kewenangan dan kewajiban kelembagaan pengawas Pemilu, (b) implementasi ketentuan terhadap petahana dan/atau kepala daerah/wakil kepala daerah yang tengah menjabat sebagai subjek hukum baru pengawasan Pilkada, serta (c) penyelenggaraan ketentuan mengenai perintah, larangan, kewajiban dan sanksi terhadap subjek hukum Pilkada dalam implementasi fungsi pengawasan tahapan-tahapan berdasarkan tingkatan dan kedudukan kewenangannya secara integratif. Urgensi penguatan kualitas PeraturanPeraturan Bawaslu tersebut memiliki makna penting sebagai komponen

\footnotetext{
${ }^{6}$. Armen Yasir, Op.Cit, p. 13.
} 
struktural sistem hukum penyelenggaraan Pilkada, serta keterkaitannya dengan validitas norma yang memberi pengaruh terhadap legitimasi dan efektifitas implementasi pengawasan Pilkada.

Hal tersebut hendaknya diarahkan kepada berjalannya fungsi Peraturan Bawaslu sebagai sub-sistem hukum penyelenggaraan Pilkada, yang meliputi Fungsi Internal yaitu memberi kepastian arah dan landasan hukum bagi jajaran pengawas Pemilu dalam penyelenggaraan tugas, kewenangan dan kewajiban yang memerlukan pengaturan lebih lanjut, sebagai regulasi dalam pembentukan ketentuan mengenai perintah, larangan, kewajiban dan sanksi, sekaligus implementasi pembinaan dan pengawasan terhadap kinerja satuan organisasi pada tingkatan dibawahnya. Selanjutnya, implementasi Fungsi Eksternal yaitu sebagai landas hukum partisipasi masyarakat sebagai social control penyelenggaraan pengawasan Pilkada sebagaimana amanat Pasal 131 ayat (2) Undang-Undang Nomor 1 Tahun 2015 a quo, serta pembentukan kepastian hukum terhadap subjek hukum Pilkada dalam implementasi pengawasan, pencegahan pelanggaran dan/atau penanganan pelanggaran.

\section{d. Penyelenggaraan Tugas, Kewenangan dan Kewajiban Dalam Penanganan Pelanggaran}

Tinjauan terhadap normatif Penindakan Pelanggaran bersifat krusial, terkait beberapa permasalahan dalam pengaturan mengenai penanganan pelanggaran berdasarkan Peraturan Bawaslu Nomor 11 Tahun 2014 a quo sebagaimana telah diubah sebagian dengan Peraturan Bawaslu Nomor 2 Tahun 2015 a quo, yang meliputi aspek substansi dan aspek teknis.

Permasalahan aspek substansi secara umum terefleksi pada lemahnya korespondensi norma-norma dasar sebagaimana amanat peraturan perundangan terhadap pengaturan mengenai implementasi penanganan pelanggaran berdasarkan Peraturan Bawaslu sebagaimana dimaksud. Hal tersebut mengemuka pada :

1) belum terdapat pengaturan terhadap petahana dan/atau Kepala Daerah/Wakil Kepala Daerah yang tengah menjabat, sebagai subjek hukum baru berdasarkan Undang-Undang Nomor 1 Tahun 2015 a quo beserta peraturan perundangan perubahannya;

2) belum adanya pengaturan implementasi kewenangan pemutusan sanksi administrasi pembatalan pasangan calon yang terbukti melakukan pelanggaran larangan menjanjikan dan/atau memberikan uang atau materi lainnya secara terstruktur, masif dan sistematis;

3) belum terdapat pengaturan implementasi kewenangan memberikan sanksi peringatan lisan atau tertulis terhadap jajaran KPU atau peserta Pilkada tidak menindaklanjuti rekomendasi pelanggaran administrasi, serta 
pengaturan mengenai tugas dan kewajiban KPU beserta jajaran dalam implementasi rekomendasi kelembagaan pengawas Pemilu;

4) penanganan pelanggaran kode etik belum mengatur (a). mekanisme koordinasi antara KPU Provinsi dan Bawaslu Provinsi dalam proses penanganan, (b). prosedur pemeriksaan, pembuktian dan tata cara penanganan, serta (c). implementasi tugas Tim Pemeriksa Daerah;

5) penanganan pelanggaran pidana belum mengatur sinergi bersama penyidik dalam Sentra Gakkumdu;

6) belum terdapat upaya antisipasi pemberlakuan pemidanaan kepada Bawaslu Provinsi dan Panwas Kabupaten/Kota atas kelalaian pelaksanaan kewajiban, serta implikasinya terhadap implementasi kewajiban pembinaan dan pengawasan oleh kelembagaan 1 (satu) tingkat di atasnya;

Permasalahan aspek teknis penanganan pelanggaran secara umum disebabkan kesenjangan norma pokok berdasarkan ketentuan UndangUndang Nomor 1 Tahun 2015 a quo beserta peraturan perundangan perubahannya, terhadap konsepsi penanganan pelanggaran berdasarkan Peraturan Bawaslu. Hal tersebut mengemuka pada

1) ketentuan tindaklanjut Temuan dan/atau Laporan pelanggaran Pilkada 7 (tujuh) hari sejak diterima dan diperpanjang paling lama 14 (empat belas), tidak berkesesuaian dengan ketentuan Pasal 134 ayat (5) dan ayat (6) Undang-Undang Nomor 8 Tahun 2015 a quo yang mengatur bahwa penanganan pelanggaran dilaksanakan paling lama 3 (tiga) dan tambahan waktu paling lama 2 (dua) hari;

2) belum adanya pengaturan ketentuan bahwa laporan pelanggaran dapat ditindaklanjuti oleh Pengawas Pemilu sebagai Temuan;

3) ketidakjelasan kaidah pengambilan alih penanganan pelanggaran pada tingkatan di bawahnya; dan

4) Ketidakjelasan kaidah mengenai kewenangan penerusan laporan/ temuan pelanggaran kepada tingkatan di bawahnya.

\section{Penutup}

\section{Simpulan}

Berdasarkan uraian hasil pembahasan, maka kesimpulan sebagai jawaban atas rumusan masalah dalam penelitian ini sebagai berikut :

a. Arah kebijakan penguatan kelembagaan pengawas Pemilu dalam penyelenggaraan Pilkada diwujudkan melalui :

1) Pemantapan kedudukan kewenangan sebagaimana amanat Pasal $22 \mathrm{E}$ ayat (5) UUD Negara Republik Indonesia Tahun 1945;

2) Perubahan secara mendasar tata hubungan kewenangan antarkelembagaan penyelenggara Pemilu; 
3) Penguatan tugas, kewenangan dan kewajiban dalam pencegahan dan penanganan pelanggaran berdasarkan tata hukum sistem kepemiluan;

4) Penguatan peran kelembagaan dalam mewujudkan Pilkada secara demokratis berdasarkan asas - asas kepemiluan;

5) Penguatan fungsi kelembagaan terhadap implementasi asas-asas kepemiluan bersifat objektif dan bersifat subjektif; dan

6) Transformasi kelembagaan pengawas Pemilu sebagai institusi kontrol penyelenggaraan Pilkada.

b. Dampak penguatan kelembagaan terhadap kapasitas lembaga dalam implementasi sistem pengawasan Pilkada terdiri dari :

1) Mekanisme dan persyaratan pembentukan kelembagaan belum menunjukkan antisipasi dampak penguatan kelembagaan terhadap efektifitas pelaksanaan tugas, kewenangan dan kewajiban, serta implementasi peran dan fungsi;

2) Kapasitas kelembagaan Panwas Kabupaten/Kota secara umum belum memadai untuk mendukung penyelenggaraan tugas, kewenangan dan kewajiban, sebagai implikasi permasalahan kedudukan bersifat ad hoc;

3) Kesenjangan pengaturan mengenai fungsi divisi-divisi terhadap uraian tugas sub-bagian dan in-proporsionalitas beban kerja sub-bagian pada Sekretariat Bawaslu Provinsi, serta belum memadainya pengaturan mengenai Pokja dalam penyelenggaraan tugas, kewenangan dan kewajiban menyebabkan kompleksitas implementasi sistem administrasi dan panatalaksanaan fungsi kelembagaan;

4) Lemahnya kualitas Peraturan-Peraturan Bawaslu mengenai implementasi fungsi pengawasan pelaksanaan tahapan-tahapan, sebagai titik lemah penguatan kapasitas kelembagaan sekaligus hambatan dakam mewujudkan efektifitas pengawasan Pilkada; dan

5) Terdapat permasalahan kekosongan norma dan kesenjangan kaidah dalam implementasi penanganan pelanggaran yang meliputi aspek substansi dan aspek teknis penanganan pelanggaran.

\section{Saran}

Berdasarkan uraian dampak penguatan kelembagaan pengawas Pemilu, maka disampaikan saran sebagai berikut :

a. Objektifikasi rekruitmen anggota pengawas Pemilu melalui penerapan computer asistant test dalam pelaksanaan tes tertulis, serta penguatan transparansi proses melalui release hasil ujian tertulis dan hasil ujian wawancara secara terbuka. Selanjutnya, ketentuan persyaratan kemampuan serta keahlian yang berkaitan dengan penyelenggaraan Pemilu dan pengawasan Pemilu dirumuskan sebagai berikut : 
1) berpendidikan paling rendah S-1 pada bidang ilmu hukum dan/atau ilmu sosial lainnya yang berkaitan dengan penyelenggaraan Pemilu;

2) memiliki kemampuan dan keahlian yang berkaitan dengan pengawasan Pemilu, wawasan hukum dan perundang-undangan; serta kemampuan ajudikasi dan teknis beracara; dan

3) pernah menjadi penyelenggara Pemilu pada tingkatannya dan/atau minimal 2 (dua) kali pada tingkatan dibawahnya.

b. Guna terciptanya kepastian hukum atas waktu pembentukan dan masa tugas pengawas Pemilu bersifat ad-hoc serta efektifitas implementasi anggaran, Bawaslu perlu berkoordinasi dengan jajaran instansi terkait dalam rangka peninjauan kembali perangkat peraturan perundangundangan mengenai ketentuan-ketentuan sebagaimana dimaksud;

c. Peningkatan tipelogi Bawaslu Provinsi dan perubahan kelembagaan pengawas Pemilu kabupaten/kota menjadi bersifat tetap dan/atau penguatan struktur organisasi pengawas Pemilu ditingkat provinsi dan kabupaten/kota;

d. Penataan kembali Peraturan-Peraturan Bawaslu mengenai Tata Kerja, Susunan Organisasi Sekretariat dan Pengawasan Tahapan yang berorientasi terciptanya sinergisitas antar kompartemen kelembagaan dalam penyelenggaraan tugas, kewenangan, dan kewajiban, serta peran dan fungsi secara integratif.

e. Penataan kembali Peraturan-Peraturan Bawaslu mengenai implementasi fungsi pengawasan pelaksanaan tahapan-tahapan Pilkada berdasarkan normatif peraturan perundangan dan antisipasi secara nyata trend/modus pelanggaran, yang berorientasi kepada peningkatan kapasitas kelembagaan; penguatan pengendalian internal dan antisipasi dampak berdasarkan manajemen resiko; sinergi dengan pemangku kepentingan; serta pengintegrasian pencegahan pelanggaran berdasarkan kedudukan dan wilayah kewenangan.

f. Penataan kembali Peraturan Bawaslu mengenai penanganan pelanggaran dan penyelesaian sengketa yang meliputi :

1) pengaturan mengenai penyelesaian sengketa mengakomodasi perkembangan norma dan kaidah berdasarkan peraturan perundangan;

2) pembentukan Peraturan Bawaslu mengenai penanganan pelanggaran dipisahkan dari pengaturan mengenai pengawasan Pemilu;

3) pengaturan mengenai penanganan pelanggaran administrasi, kode etik serta pidana dilaksanakan berdasarkan Peraturan Bawaslu yang terpisah dan secara khusus mengatur mengenai hal tersebut; dan

4) penyusunan substansi Peraturan Bawaslu sebagaimana di atas dilaksanakan berdasarkan norma dan kaidah peraturan perundangan, serta mengakomodasi pengaturan pengendalian internal, 
pengintegrasian fungsi divisi-divisi terkadap uraian tugas sub-bagian dan implementasi Pokja-Pokja.

\section{Daftar Pustaka}

\section{A. Buku dan Jurnal}

Sardini, Nurhidayat. (2009). Pedoman Pengawasan Pemilu. Jakarta: Election-MDP.

Satriawan, Iwan. (2016). "Pengawasan Pemilukada oleh Rakyat". Jurnal Bawaslu 2(1).

\section{B. Sumber Lain}

Undang-Undang Nomor 22 Tahun 2014 tentang Pemilihan Gubernur, Bupati dan Walikota.

Muyassarotussolichah. "Melacak Akar, Cabang dan Ranting Politik Hukum UUD 1945 Hasil Amandemen". http://ern.pendis.kemenag.go.id, (dikutip tanggal 29 Juli 2016). 